\title{
Decoupling Hypothesis and the Financial Crisis
}

\author{
Joanna Wyrobek ${ }^{1}$, Zbigniew Stańczyk ${ }^{2}$ \\ ${ }^{1}$ Cracow University of Economics \\ Department of Corporate Finance \\ ul. Rakowicka 27, 31-510 Kraków \\ E-mail: wyrobekj@uek.krakow.pl \\ ${ }^{2}$ Cracow University of Economics \\ Department of Macroeconomics \\ ul. Rakowicka 27, 31-510 Kraków \\ E-mail: stanczyz@uek.krakow.pl
}

\begin{abstract}
The purpose of this paper was to present the decoupling hypothesis which says that the performance of emerging economies becomes relatively independent of the changes in advanced economies, and to empirically verify this hypothesis. The Christiano-Fitzgerald bandpass filter and spectral analyses have been applied to examine the hypothesis. On the basis of obtained results, comparing the deviations of GDPs from their long-term trend, it seems that the synchronization of cycles between emerging and advanced economies was already high before the crisis. The last global crisis, especially if time shifts between the countries are taken into account, even increased the synchronization of the economies. Therefore, this paper presents evidence against the decoupling hypothesis, and at the same time it raises doubts whether the high GDP growth rates in emerging economies can be sustainable in the presence of the slow-down in the advanced economies. The paper analyzes the situation from the Poland's point of view as the country which is on the verge of joining the ERM2 system and adopting the euro (synchronization divagations are important for this decision) and because Poland is a good example of an emerging economy.
\end{abstract}

Keywords: decoupling, business cycle synchronization, spectral analysis, emerging economies

JEL codes: $F 44, C 32, O 1$

\section{Introduction}

The decoupling hypothesis has its origins in the spectacular successes of the economies of China and India, whose high growth rates do not seem to be influenced by the parlous state or the shocks sustained by them. Some years ago it appeared as if the decoupling hypothesis could be applied, not only to certain Asian countries but it can also be used to 
describe the performance of certain Latin American countries, for example, Brazil. Indeed, some Latin American countries started to grow faster than the U.S. economy and their growth path now appears to have become independent of the economic situation in the U.S. However, the decoupling can mean different things, and it can be measured in different things. As it is stressed by Dervis (2012), firstly it can mean the divergence of the GDP long-term path of emerging economies and advanced economies. However, according to many macroeconomic models, for example the Solow model, catching-up economies should have higher rates of growth. Hence, higher long-term growth rates in emerging economies are not indicators of growing differences between advanced and emerging economies. Secondly, the decoupling can mean the growing differences between business cycles and the growing differences in reaction to global shocks. Dervis (2012) also calls it a delinking of cyclical movements, and it is the most common meaning of the decoupling.

The decoupling hypothesis has become a very popular topic since the beginning of the last global financial crisis, and many articles in business newspapers and magazines have been written about it (Decoupling 2.0, 2009 , is a good example of such a publication). However, very seldom can one find comprehensive statistical and econometric studies on it. We can find some studies on business cycles synchronization between emerging European countries and the EU (Adamowicz at al., 2009; Konopczak, 2009; and Skrzypczyński 2010) but there are few publications on the decoupling hypothesis which include a wider selection of emerging markets and long time series. In the opinion of the authors of this paper, Kose et al. (2008), Kose and Prasad (2010), World Economic Outlook (2007) and Wälti (2009) are the best examples of such publications.

Research conducted before the last global financial crisis did not provide an answer as to whether the decoupling hypothesis was valid or not: in fact, research papers were almost equally divided between confirming and rejecting this hypothesis. The most often quoted paper supporting the hypothesis is that of Kose et al. (2008), who examined the degree of synchronization in 106 economies during the years 1960-2005. In this study, a sample of countries was divided into three groups: advanced economies, emerging market economies and other developing 
economies, and three time series were taken into account: GDP, investment, and consumption. The variances of the time series were decomposed into variances of three factors and an idiosyncratic component. The following factors were taken into account: the global factor, which was related to fluctuations in all countries; the group factor which characterised the fluctuations of every group of countries; and finally, the country-specific factor. Kose et al. (2008) reported that their most important finding was that the synchronization of cycles increased independently for advanced and emerging economies in the years 19852005. On the other hand, according to the authors, the impact of the global factor decreased when periods 1960-1984 and 1985-2005 were compared, and this finding is supposed to show that a decoupling of advanced and emerging economies had taken place. The theses of Kose et al. (2008) were reiterated by Kose and Prasad (2010) for longer time series.

Their results were supported by the IMF's World Economic Outlook (2007, p. 139-143), but the authors of this report grouped countries not according to the level of development, but according to certain regional criteria. Table 1 presents the results of variance decomposition into global, regional, country-specific, and idiosyncratic factors. The report then claims that in the years 1985-2005, regional, and not global, factors were more important for GDP fluctuations (table 1 ).

Table 1 Contributions to output; unweighted averages for every region; percentages

\begin{tabular}{lcccc}
\hline & $\begin{array}{c}\text { Global } \\
\text { factor }\end{array}$ & $\begin{array}{c}\text { Regional } \\
\text { factor }\end{array}$ & $\begin{array}{c}\text { Country } \\
\text { factor }\end{array}$ & $\begin{array}{c}\text { Idiosyncratic } \\
\text { 1960- 2005 }\end{array}$ \\
\hline North America & 16.9 & 51.7 & 14.8 & 16.6 \\
Western Europe & 22.7 & 21.6 & 34.6 & 21.1 \\
Emerging Asia and Japan & 7.0 & 21.9 & 47.4 & 23.7 \\
Latin America & 9.1 & 16.6 & 48.6 & 25.7 \\
\hline 1960- 85 & & & & \\
North America & 31.4 & 36.4 & 15.7 & 16.5 \\
Western Europe & 26.6 & 20.5 & 31.6 & 21.3 \\
Emerging Asia and Japan & 10.6 & 9.5 & 50.5 & 29.4 \\
Latin America & 16.2 & 19.4 & 41.2 & 23.2 \\
\hline 1986- 2005 & & & & \\
North America & 5.0 & 62.8 & 8.2 & 24.0 \\
Western Europe & 5.6 & 38.3 & 27.6 & 28.5 \\
Emerging Asia and Japan & 6.5 & 34.7 & 31.1 & 27.7 \\
Latin America & 7.8 & 8.7 & 51.7 & 31.8 \\
\hline
\end{tabular}

Source: World Economic Outlook (2007, p. 14) 
Similar conclusions, yet concerning only the real part of the economy (not the financial sector) can be found in the 2012 World Bank's working paper by Yeyati and Williams. Independently of the conclusions stated in the paper, the authors' calculations confirmed positive, statistically significant and stable in time beta coefficients between real GDP changes (cyclical parts) of the emerging economies and the G7 group (Yeyati, Williams, 2012).

A study by Wälti (2009) is one of the most important papers which rejected the decoupling hypothesis. Conducting calculations for thirty four emerging markets and 29 advanced economies, he examined GDP deviations from their long-term trend and compared them for a different time shift. The emerging market economies came from four different regions of the world: eight East and South Asian economies, nine Latin American countries, thirteen Eastern and South European economies, and four other economies from Africa and Middle East. Advanced economies were grouped in four ways: all advanced economies, the European group, the G7 group, and the United States alone. The Hodrick-Prescott filter and spectral analyses were used for the period 1980-2007. The results presented by Wälti (2009) refuted the decoupling hypothesis - the strength of ties for countries from different continents turned to be similar to that between advanced and emerging economies.

Doubts about decoupling became even more pronounced in the aftermath of the subprime crisis when practically all countries (from all regions, both rich and poor) were affected by the crisis. Certain economists (for example, Skrzypczyński, 2010, Rose, 2009, Krugman, 2010, and Dervis, 2012) say that the decoupling has never existed, and others (for example, Korinek et al., 2010) suggest that the change in the economic conditions occurred, and we face the phase of re-coupling after the phase of decoupling (in other words, after the phase of low synchronization of business cycles we could see re-synchronization of business cycles between advanced and emerging economies, and between economies from different continents).

The aim of this paper is to verify the hypothesis whether the changes which occurred during and after the global crisis should be treated as a kind of re-coupling or whether the whole decoupling hypothesis should be 
rejected. Poland is used as a reference country for the purpose of the calculations carried out.

\section{Methodology and Data}

The time series analysis used in this paper is based on the approach described in Hamilton (1994), who gives a comprehensive description of these methods (an interesting discussion about practical application of the methods can be found in Skrzypczyński (2010). Firstly, time series (in our case: GDP growth rates calculated on the basis of quarterly data from the World Bank database) had time trends and (if applicable) drifts removed and then the resulting time series were subjected to the Christiano-Fitzgerald filter, and finally to spectral analysis. The methods are briefly presented below. The time period chosen for the analysis depended mostly on: the availability of data, high requirements of the research method for long time series and the purpose of the paper which was to compare synchronization before and during the last global crisis (the authors used 2 datasets: for years 1995-2006 and 1995-2009).

\section{An outline of the Christiano-Fitzgerald band-pass filter}

As it has already been mentioned, the Christiano-Fitzgerald band-pass filter is used to extract the cyclical part of the time series. The filter was chosen because of its applicability to almost all time series and its advantages over other methods (it takes into account stochastic structure of the decomposed variable, removes all non-seasonal fluctuations, etc.). The Christiano-Fitzgerald filter requires testing of the stationarity of time series (time series can be: stationary $\mathrm{I}(0)$, trend stationary or nonstationary $\mathrm{I}(1)$ ). The filter requires the removal of time-trend (if it is present) and for processes stationary at $\mathrm{I}(1)$ one must remove a drift (if it is present) (Skrzypczyński, 2008, p. 13-14).

The idea of calculating the cyclic component $\hat{y}_{t}^{c}$ in the band pass filter is based on the following formula (Nilsson, Gyomai, 2011, p. 7-8):

$\hat{y}_{t}^{c}=\hat{B}_{t}(L) y_{t}$, where $\hat{B}_{t}(L)=\sum_{j=-(T-t)}^{t-1} \hat{B}_{j, t} L^{j}$ for $t=1,2 \ldots, T$.

In the formula, $L$ stands for the lag operator of $y$ and $B$ represents a set of parameters (weights) (Christiano, Fitzgerald, 1999, p. 2). The set of weights $\hat{B}_{j, t}$ is the solution of the equation: 


$$
\min _{\hat{B}_{j, t}, j=-(T-t), \ldots, t-1} \int_{-\pi}^{\pi}\left|B\left(e^{-i \omega}\right)-\hat{B}_{t}\left(e^{-i \omega}\right)\right|^{2} S_{y}(\omega) d \omega \quad \text { for } t=1,2, \ldots ., T \text {. }
$$

For the CF filter for the $\mathrm{I}(1)$ series there is an additional (limiting) condition that: $\sum_{j=-(T-t)}^{t-1} \hat{B}_{j, t}=0$ for $\mathrm{t}=1,2, \ldots . \mathrm{T}$, which provides for removal by filter of a stochastic trend. Operation of the filter, which involves the removal frequencies which are too low or too high to be treated as part of the business cycle, is based on the function $B\left(e^{-i \omega}\right)$, which is defined as follows:

$$
B\left(e^{-i \omega}\right) \equiv\left\{\begin{array}{l}
1 \text { for } \omega \in[-\bar{\omega},-\underline{\omega}] \cup[\underline{\omega}, \bar{\omega}], \\
0 \text { for } \omega \in[-\pi,-\bar{\omega}) \cup(-\underline{\omega}, \underline{\omega}) \cup(\bar{\omega}, \pi],
\end{array}\right.
$$

where: $\omega=2 \pi / \tau$ is the frequency expressed in radians with a period equal to $\tau$. Figures $\underline{\omega}=2 \pi / \tau_{U}$ and $\bar{\omega}=2 \pi / \tau_{L}(0<\underline{\omega}<\bar{\omega}<\pi)$ determine the lower and upper frequency of the filter, which causes the filter to cut off fluctuations with a period longer than $\tau_{U}$ and less than $\tau_{L}$. The calculations assumed $\tau_{U}=32$ and $\tau_{L}=6$.

\section{An outline of a single spectrum analysis method}

The origin of spectral analysis is based on the idea of representing time series as the sum of sinusoids at various frequencies (cycles). Spectral analysis of cyclic data requires the Fourier transform, which is used to transform the time domain representation of the series into the frequency domain representation of the series. In order to determine the significance of different frequencies in data, one calculates a spectrogram. The spectrogram displays the power of a signal as a function of both: time and frequency simultaneously.

According to Skrzypczyński (2008, p. 16): "power spectrum of a stochastic process with discrete time $\left\{y_{t}\right\}_{t=-\infty}^{+\infty}$ with a zero mean and stationary covariance function is defined as the Fourier transform of autocovariance series $\left\{y_{k}^{v}\right\}_{k=-\infty}^{+\infty}$ of this process and is given as:

$S_{y}(\omega)=\frac{1}{2 \pi} \sum_{k=-\infty}^{+\infty} \gamma_{k}^{y} e^{-i \varpi k}$ for $\omega \in[-\pi, \pi]$, where $\omega=\frac{2 \pi}{\tau}$ is the frequency corresponding to the period $\tau$ ". Due to the fact that the spectrogram 
calculated using the above method is very "fuzzy", certain methods are used to reduce this variability (smoothing methods), and one of the most popular is the Parzen window. The power spectrum estimator then takes the form (Skrzypczyński, 2008, p. 17, quoting Chatfield, 1996, p. 115) where empirical autocovariances are

$$
\begin{aligned}
& \hat{S}(\omega)=\frac{1}{2 \pi} \sum_{k=-H}^{H} w_{k} \hat{\gamma}_{k}^{y} e^{-i \omega k}=\frac{1}{2 \pi}\left[w_{0} \hat{\gamma}_{0}^{y}+2 \sum_{k=1}^{H} w_{k} \hat{\gamma}_{k}^{y} \cos (\omega k)\right], \\
& \hat{\gamma}_{k}^{y}=\frac{1}{T} \sum_{t=1+k}^{T}\left(y_{t}-\bar{y}\right)\left(y_{t-k}-\bar{y}\right) \text { for } k=0,1, \ldots T-1,
\end{aligned}
$$

and Parzen window weights are:

$$
w_{k}=\left\{\begin{array}{l}
1-6(k / H)^{2}+6(|k| / H)^{3} \text { for }|k| \leq H / 2, \\
2(1-|k| / H)^{3} \text { for } H / 2 \leq|k| \leq H \\
0 \text { for }|k|>H
\end{array}\right.
$$

The maximum allowable lag time for Parzen window, called the truncation lag, is chosen according to the rule $H=\operatorname{int}(2 \sqrt{T})$.

\section{Outline of the cross-spectral analysis}

"Cross spectral analysis allows one to determine the relationship between two time series as a function of frequency. Normally, one supposes that statistically significant peaks at the same frequency have been shown in two time series as that we wish to see if these periodicities are related with each other and, if so, what the phase relationship (time shift) is between them (Hartmann, 2008, p. 165)". We can do cross spectral analysis even in the absence of peaks in the power spectrum because even without common peaks there might be coherent modes at particular frequencies. In this paper, however, attention will be paid to common peaks in two time series.

There are several methods of calculating the cross-spectrum, one of which is given by Bloomfield (1976, p. 210-212). The time series $X$ and $Y$ can first be "combined" in the time domain (before the Fourier transform) by calculating the lagged cross-covariance function. The resulting 
function is then subjected to a Fourier transform and a cross spectrum periodogram is obtained. Cross-covariance can be written as:

$$
\begin{aligned}
& c_{x, y, r}=\frac{1}{n} \sum x_{t} y_{t-r}, \text { where } \mathrm{t} \text { and } \mathrm{t}-\mathrm{r}=0,1,2, \\
& \ldots . ., \mathrm{n}-1,
\end{aligned}
$$

and $r$ means a time lag of one series relative to the other.

The Fourier transform is then carried out to obtain the cross-spectrum periodogram:

$$
I_{x, y}(\omega)=\frac{1}{2 \pi} \sum_{|r|<n} c_{x, y, r} e^{-i r \sigma} .
$$

Similarly to the single spectrum periodogram (spectrogram), the crossspectrum periodogram is also smoothed, e.g. by a Parzen window.

For cross-spectrum analysis, we usually calculate the following three measures: squared coherence, gain value and phase shift between the series. The squared coherence measures the strength of association between two series, the gain (value) estimates the magnitude of changes of one time series in relation to the other for a certain frequency, the phase shift estimates to which extent each frequency component of one series leads the other.

Quoting Skrzypczyński (2008, p. 17-18) once again: "if we assume that a stochastic process with discrete time $\left\{x_{t}\right\}_{t=-\infty}^{+\infty}$ with zero mean and stationary covariance function is an independent variable, whereas the process $\left\{y_{t}\right\}_{t=-\infty}^{+\infty}$ of the analogous properties is the dependent variable, then the cross power spectrum (cross-spectral density, cross-spectrum) of these variables is defined as the Fourier transform $\left\{\gamma_{k}^{y x}\right\}_{t=-\infty}^{+\infty}$ of the cross-covariance series of these variables and is given by this formula:

$$
S_{y x}(\omega)=\frac{1}{2 \pi} \sum_{k=-\infty}^{+\infty} \gamma_{k}^{y x} e^{-i \omega k}=c_{y x}(\omega)-i q_{y x}(\omega) \text { for } \omega \in[-\pi, \pi] \text {, }
$$

where:

$$
c_{y x}(\omega)=2 \pi^{-1} \sum_{k=-\infty}^{+\infty} \gamma_{k}^{y x} \cos (\omega k)
$$


is called co-spectrum and is a real part of cross-spectrum, while

$$
q_{y x}(\omega)=2 \pi^{-1} \sum_{k=-\infty}^{+\infty} \gamma_{k}^{y x} \sin (\omega k)
$$

is called the quadrature spectrum, is a negative imaginary part of the cross-spectrum. It is possible to define three cross-spectral statistics on the basis of cross power spectrum: gain value $\left(G_{y x}(\omega)\right.$ ), phase shift ( $\varphi_{y x}(\omega)$ ), and squared coherence $\left(K_{y x}^{2}(\omega)\right)$ :

$$
\begin{aligned}
& G_{y x}(\omega)=\frac{\left(c_{y x}^{2}(\omega)+q_{y x}^{2}(\omega)\right)^{\frac{1}{2}}}{S_{x}(\omega)} \text { for } \omega \in[-\pi, \pi], \\
& \varphi_{y x}(\omega)=\tan ^{-1}\left(\frac{-q_{y x}(\omega)}{c_{y x}(\omega)}\right) \text { for } \omega \in[-\pi, \pi], \\
& K_{y x}^{2}(\omega)=\frac{c_{y x}^{2}(\omega)+q_{y x}^{2}(\omega)}{S_{y}(\omega) S_{x}(\omega)} \text { for } \omega \in[-\pi, \pi],
\end{aligned}
$$

where: $S_{x}(\omega)$ means power spectrum of the process $\left\{x_{t}\right\}$, while $S_{y}(\omega)$ means power spectrum of the process $\left\{y_{t}\right\}$ ".

\section{Results}

The strength of the relationship between cycles (in addition to the length of the business cycle) of a particular country with other countries may indicate a strong relationship between their economies. In the case of spectral analysis, the strength of the relationship between cycles is measured by the squared coherence: the higher the coherence, the stronger the relationship.

Tables 2 and 3 show the squared coherences calculated by the authors. The bold numbers indicate very high coherences (80-100\%), and the coherences between 60 and $80 \%$ can also be treated as quite high. As can be seen in the tables, when the squared coherences for different frequencies (lengths of cycles) are considered, business cycles all over the world were quite similar even before the global financial crisis, and it 
is more evident for longer and very short cycles. The results are presented from Poland's perspective and it can be seen that countries on one continent do have strong connections with each other. In this case, Poland's business cycle is very similar to other European countries cycles. Nonetheless, when long business cycles are considered, Poland had a stronger coherence with the United States than with any European country, even its main economic partner, Germany, which became especially visible during the global economic crisis. Also, assuming high coherences with small Asian countries irrelevant, Poland had a relatively high coherence with another huge economy - China. When short business cycles are to be considered, Poland's economy visibly belonged to the group of the European countries, especially members of the EU.

When Tables 2 and 3 are compared, it seems that the relations of Poland with the richest European countries have become even stronger for the last years, so one cannot say that the decoupling has occurred in the case of Poland. The financial crises could influence the results; on the other hand, during the crisis Poland was doing quite well. It was the only EU country with a positive rate of growth in 2009 when there was a fall of GDP in rich European countries. Other emerging European economies have also stronger ties with advanced European economies than with new members of the EU.

According to the results in Tables 2 and 3, the synchronization of cycles between Poland and emerging economies from Asia and Latin America has increased for the last years. Not presented in the paper (for the sake of its brevity), other diagrams and calculations also suggest that real GDP deviations from the long-term trend in the above mentioned countries became more similar. The diagrams unanimously show that during the crisis all economies slowed down and the short-term real GDP curves bent down from the trend. It seems that all emerging countries succumb to external global shocks, and therefore, the decoupling of the real economies can hardly be acknowledged. The defenders of the decoupling hypothesis can argue that it was only a one-time event, but such an argument does not seem to be very strong: emerging economies seem to exhibit high sensitivity to global shocks. They reacted similarly to other global shocks, no matter where the origin of the shock was, either in advanced or developing economies. One can enumerate the Asian crisis of 1987 or the current situation in the EU. 
Table 2 Coherence coefficients between the business cycle in Poland and other countries (different cycle length); calculations for years 1995-2006, grouped by continents

Europe

\begin{tabular}{|c|c|c|c|c|c|c|c|}
\hline Country & 24 & 16 & 12 & 9.6 & 8 & 6.90 & 6 \\
\hline Austria & $85.5 \%$ & $56.7 \%$ & $30.7 \%$ & $59.7 \%$ & $49.2 \%$ & $51.4 \%$ & $50.8 \%$ \\
\hline Belgium & $83.3 \%$ & $59.6 \%$ & $43.9 \%$ & $83.8 \%$ & $87.0 \%$ & $74.9 \%$ & $51.9 \%$ \\
\hline Croatia & $83.3 \%$ & $55.6 \%$ & $68.2 \%$ & $79.1 \%$ & $63.8 \%$ & $62.6 \%$ & $52.5 \%$ \\
\hline Czech Rep. & $86.3 \%$ & $44.6 \%$ & $4.9 \%$ & $6.4 \%$ & $46.5 \%$ & $70.6 \%$ & $73.4 \%$ \\
\hline Denmark & $81.6 \%$ & $49.1 \%$ & $24.7 \%$ & $10.4 \%$ & $5.9 \%$ & $10.2 \%$ & $5.8 \%$ \\
\hline Estonia & $26.6 \%$ & $6.7 \%$ & $15.5 \%$ & $32.2 \%$ & $51.4 \%$ & $62.4 \%$ & $44.1 \%$ \\
\hline Finland & $85.4 \%$ & $67.3 \%$ & $60.7 \%$ & $34.2 \%$ & $8.3 \%$ & $5.6 \%$ & $23.6 \%$ \\
\hline France & $92.5 \%$ & $81.8 \%$ & $64.7 \%$ & $59.0 \%$ & $44.5 \%$ & $58.3 \%$ & $68.3 \%$ \\
\hline Georgia & $15.4 \%$ & $7.2 \%$ & $8.8 \%$ & $4.8 \%$ & $14.5 \%$ & $7.2 \%$ & $55.8 \%$ \\
\hline Germany & $87.3 \%$ & $65.1 \%$ & $50.0 \%$ & $33.2 \%$ & $35.1 \%$ & $66.4 \%$ & $59.0 \%$ \\
\hline G. Britain & $93.2 \%$ & $80.8 \%$ & $62.9 \%$ & $34.7 \%$ & $45.6 \%$ & $62.5 \%$ & $55.4 \%$ \\
\hline Hungary & $76.4 \%$ & $41.1 \%$ & $28.7 \%$ & $28.8 \%$ & $17.9 \%$ & $42.2 \%$ & $29.3 \%$ \\
\hline Iceland & $26.8 \%$ & $5.1 \%$ & $16.2 \%$ & $54.6 \%$ & $79.6 \%$ & $65.9 \%$ & $48.4 \%$ \\
\hline Ireland & $83.1 \%$ & $53.5 \%$ & $45.6 \%$ & $31.9 \%$ & $26.3 \%$ & $28.9 \%$ & $41.8 \%$ \\
\hline Italy & $87.5 \%$ & $76.2 \%$ & $68.2 \%$ & $61.0 \%$ & $39.8 \%$ & $45.2 \%$ & $72.4 \%$ \\
\hline Latvia & $61.7 \%$ & $22.4 \%$ & $16.7 \%$ & $34.2 \%$ & $37.0 \%$ & $56.1 \%$ & $62.4 \%$ \\
\hline Lithuania & $1.6 \%$ & $6.6 \%$ & $12.2 \%$ & $41.1 \%$ & $48.6 \%$ & $47.4 \%$ & $31.7 \%$ \\
\hline Netherlands & $94.3 \%$ & $77.7 \%$ & $48.8 \%$ & $27.3 \%$ & $26.7 \%$ & $57.1 \%$ & $59.9 \%$ \\
\hline Norway & $10.9 \%$ & $10.4 \%$ & $19.1 \%$ & $70.2 \%$ & $81.0 \%$ & $64.2 \%$ & $48.2 \%$ \\
\hline Portugal & $90.7 \%$ & $59.2 \%$ & $8.4 \%$ & $46.6 \%$ & $57.0 \%$ & $75.0 \%$ & $71.3 \%$ \\
\hline Russia & $94.7 \%$ & $81.5 \%$ & $79.6 \%$ & $74.7 \%$ & $72.0 \%$ & $73.7 \%$ & $80.0 \%$ \\
\hline Slovakia & $51.1 \%$ & $56.8 \%$ & $49.1 \%$ & $65.0 \%$ & $84.1 \%$ & $66.5 \%$ & $17.8 \%$ \\
\hline Slovenia & $79.9 \%$ & $42.8 \%$ & $40.5 \%$ & $38.7 \%$ & $4.4 \%$ & $5.9 \%$ & $30.1 \%$ \\
\hline Spain & $92.0 \%$ & $68.1 \%$ & $53.3 \%$ & $72.1 \%$ & $66.3 \%$ & $56.4 \%$ & $67.5 \%$ \\
\hline Sweden & $87.1 \%$ & $62.2 \%$ & $50.4 \%$ & $53.3 \%$ & $46.1 \%$ & $32.9 \%$ & $40.7 \%$ \\
\hline Switzerland & $84.8 \%$ & $64.9 \%$ & $64.0 \%$ & $75.2 \%$ & $48.0 \%$ & $4.8 \%$ & $4.7 \%$ \\
\hline Turkey & $67.6 \%$ & $48.4 \%$ & $63.3 \%$ & $49.7 \%$ & $32.7 \%$ & $2.0 \%$ & $20.4 \%$ \\
\hline EU 27 & $90.3 \%$ & $73.3 \%$ & $62.7 \%$ & $47.6 \%$ & $45.2 \%$ & $63.2 \%$ & $71.0 \%$ \\
\hline Euro 17 & $90.1 \%$ & $73.2 \%$ & $62.9 \%$ & $52.0 \%$ & $48.5 \%$ & $65.8 \%$ & $78.6 \%$ \\
\hline \multicolumn{8}{|c|}{ North and South America } \\
\hline Country & 24 & 16 & 12 & 9.6 & 8 & 6.90 & 6 \\
\hline Argentina & $64.6 \%$ & $28.4 \%$ & $54.0 \%$ & $28.5 \%$ & $13.2 \%$ & $27.7 \%$ & $54.2 \%$ \\
\hline Bolivia & $60.2 \%$ & $32.8 \%$ & $18.3 \%$ & $64.9 \%$ & $67.4 \%$ & $39.6 \%$ & $31.9 \%$ \\
\hline Brazil & $81.0 \%$ & $65.4 \%$ & $40.8 \%$ & $24.3 \%$ & $2.0 \%$ & $12.4 \%$ & $24.8 \%$ \\
\hline Canada & $88.5 \%$ & $69.4 \%$ & $66.8 \%$ & $45.3 \%$ & $2.6 \%$ & $15.3 \%$ & $20.5 \%$ \\
\hline Chile & $2.2 \%$ & $16.7 \%$ & $38.6 \%$ & $73.7 \%$ & $81.5 \%$ & $83.6 \%$ & $76.2 \%$ \\
\hline Colombia & $58.2 \%$ & $35.1 \%$ & $49.6 \%$ & $78.2 \%$ & $83.3 \%$ & $84.6 \%$ & $62.0 \%$ \\
\hline Mexico & $80.3 \%$ & $58.9 \%$ & $59.1 \%$ & $37.4 \%$ & $34.8 \%$ & $50.5 \%$ & $45.9 \%$ \\
\hline Peru & $49.8 \%$ & $7.6 \%$ & $48.4 \%$ & $62.5 \%$ & $19.5 \%$ & $2.8 \%$ & $11.5 \%$ \\
\hline USA & $94.3 \%$ & $81.6 \%$ & $62.1 \%$ & $23.2 \%$ & $7.3 \%$ & $16.3 \%$ & $7.6 \%$ \\
\hline \multicolumn{8}{|l|}{ Asia } \\
\hline Country & 24 & 16 & 12 & 9.6 & 8 & 6.90 & 6 \\
\hline China & $62.3 \%$ & $27.3 \%$ & $19.1 \%$ & $3.2 \%$ & $29.6 \%$ & $48.0 \%$ & $58.0 \%$ \\
\hline Hong Kong & $68.7 \%$ & $51.2 \%$ & $42.0 \%$ & $51.0 \%$ & $30.1 \%$ & $35.4 \%$ & $39.7 \%$ \\
\hline India & $63.9 \%$ & $32.2 \%$ & $0.9 \%$ & $26.6 \%$ & $34.0 \%$ & $57.6 \%$ & $71.1 \%$ \\
\hline Indonesia & $68.5 \%$ & $24.2 \%$ & $15.7 \%$ & $63.7 \%$ & $79.0 \%$ & $72.9 \%$ & $64.1 \%$ \\
\hline Iran & $53.0 \%$ & $11.4 \%$ & $7.7 \%$ & $15.4 \%$ & $37.2 \%$ & $30.0 \%$ & $15.4 \%$ \\
\hline Israel & $87.6 \%$ & $86.3 \%$ & $73.1 \%$ & $55.7 \%$ & $34.6 \%$ & $2.7 \%$ & $26.7 \%$ \\
\hline Japan & $61.8 \%$ & $49.1 \%$ & $36.3 \%$ & $5.5 \%$ & $12.7 \%$ & $6.7 \%$ & $16.4 \%$ \\
\hline
\end{tabular}




\begin{tabular}{|c|c|c|c|c|c|c|c|}
\hline Country & 24 & 16 & 12 & 9.6 & 8 & 6.90 & 6 \\
\hline Malaysia & $38.8 \%$ & $22.0 \%$ & $52.0 \%$ & $72.5 \%$ & $65.4 \%$ & $70.0 \%$ & $69.6 \%$ \\
\hline Philippines & $22.4 \%$ & $4.7 \%$ & $40.4 \%$ & $14.5 \%$ & $23.8 \%$ & $3.3 \%$ & $14.7 \%$ \\
\hline Singapore & $84.7 \%$ & $77.8 \%$ & $64.6 \%$ & $52.0 \%$ & $33.6 \%$ & $41.5 \%$ & $35.9 \%$ \\
\hline South Korea & $76.4 \%$ & $28.1 \%$ & $40.6 \%$ & $66.0 \%$ & $42.3 \%$ & $45.5 \%$ & $56.9 \%$ \\
\hline Taiwan & $98.6 \%$ & $97.5 \%$ & $86.7 \%$ & $34.5 \%$ & $7.9 \%$ & $3.3 \%$ & $22.5 \%$ \\
\hline Thailand & $50.9 \%$ & $17.3 \%$ & $31.9 \%$ & $53.1 \%$ & $45.6 \%$ & $68.2 \%$ & $79.0 \%$ \\
\hline \multicolumn{8}{|c|}{ Australia and Oceania } \\
\hline Country & 24 & 16 & 12 & 9.6 & 8 & 6.90 & 6 \\
\hline Australia & $56.8 \%$ & $42.5 \%$ & $19.1 \%$ & $10.0 \%$ & $2.0 \%$ & $8.1 \%$ & $23.9 \%$ \\
\hline N. Zealand & $39.8 \%$ & $45.1 \%$ & $77.8 \%$ & $85.0 \%$ & $70.2 \%$ & $40.1 \%$ & $9.7 \%$ \\
\hline \multicolumn{8}{|l|}{ Africa } \\
\hline Country & 24 & 16 & 12 & 9.6 & 8 & 6.90 & 6 \\
\hline Morocco & $45.1 \%$ & $45.4 \%$ & $43.2 \%$ & $46.4 \%$ & $56.3 \%$ & $67.0 \%$ & $36.9 \%$ \\
\hline South Africa & $87.4 \%$ & $45.5 \%$ & $19.9 \%$ & $17.2 \%$ & $10.5 \%$ & $37.1 \%$ & $61.3 \%$ \\
\hline
\end{tabular}

Source: authors' own calculations based on World Bank data

Table 3 Coherence coefficients between the business cycle in Poland and other countries (different cycle length); calculations for years 1995-2009, grouped by continents

Europe

\begin{tabular}{|c|c|c|c|c|c|c|c|c|c|}
\hline Country & 30 & 20 & 15 & 12 & 10 & 8.57 & 7.5 & 6.67 & 6 \\
\hline Austria & $84.8 \%$ & $76.1 \%$ & $72.2 \%$ & $46.7 \%$ & $46.4 \%$ & $60.5 \%$ & $39.0 \%$ & $14.4 \%$ & $20.3 \%$ \\
\hline Belgium & $65.1 \%$ & $51.3 \%$ & $57.7 \%$ & $35.4 \%$ & $41.7 \%$ & $63.4 \%$ & $59.9 \%$ & $49.9 \%$ & $25.0 \%$ \\
\hline Croatia & $68.3 \%$ & $60.7 \%$ & $62.1 \%$ & $64.8 \%$ & $80.9 \%$ & $77.2 \%$ & $51.6 \%$ & $70.2 \%$ & $77.3 \%$ \\
\hline Czech Rep. & $63.9 \%$ & $55.2 \%$ & $58.8 \%$ & $50.7 \%$ & $42.4 \%$ & $14.0 \%$ & $1.2 \%$ & $44.7 \%$ & $84.0 \%$ \\
\hline Denmark & $83.2 \%$ & $75.1 \%$ & $71.4 \%$ & $78.2 \%$ & $77.7 \%$ & $56.0 \%$ & $11.9 \%$ & $4.5 \%$ & $38.9 \%$ \\
\hline Estonia & $63.4 \%$ & $43.7 \%$ & $36.9 \%$ & $64.2 \%$ & $84.7 \%$ & $71.5 \%$ & $14.0 \%$ & $26.2 \%$ & $65.4 \%$ \\
\hline Finland & $87.4 \%$ & $82.9 \%$ & $82.0 \%$ & $82.7 \%$ & $83.9 \%$ & $68.2 \%$ & $17.3 \%$ & $6.0 \%$ & $44.1 \%$ \\
\hline France & $85.2 \%$ & $80.8 \%$ & $82.3 \%$ & $85.4 \%$ & $87.3 \%$ & $80.1 \%$ & $45.6 \%$ & $9.8 \%$ & $28.2 \%$ \\
\hline Georgia & $2.6 \%$ & $32.2 \%$ & $58.4 \%$ & $73.2 \%$ & $46.9 \%$ & $45.7 \%$ & $54.9 \%$ & $27.6 \%$ & $88.7 \%$ \\
\hline Germany & $79.6 \%$ & $69.2 \%$ & $72.3 \%$ & $85.0 \%$ & $89.0 \%$ & $74.4 \%$ & $27.3 \%$ & $21.2 \%$ & $65.9 \%$ \\
\hline G. Britain & $86.3 \%$ & $84.4 \%$ & $84.9 \%$ & $81.3 \%$ & $79.9 \%$ & $70.7 \%$ & $30.2 \%$ & $12.1 \%$ & $63.7 \%$ \\
\hline Hungary & $88.4 \%$ & $83.8 \%$ & $73.4 \%$ & $72.7 \%$ & $80.6 \%$ & $65.2 \%$ & $22.5 \%$ & $16.7 \%$ & $67.8 \%$ \\
\hline Iceland & $75.1 \%$ & $47.4 \%$ & $53.9 \%$ & $58.0 \%$ & $24.9 \%$ & $0.4 \%$ & $32.1 \%$ & $70.3 \%$ & $84.5 \%$ \\
\hline Ireland & $80.0 \%$ & $71.8 \%$ & $73.6 \%$ & $85.8 \%$ & $89.4 \%$ & $77.2 \%$ & $33.8 \%$ & $15.6 \%$ & $2.0 \%$ \\
\hline Italy & $76.9 \%$ & $67.5 \%$ & $68.5 \%$ & $81.1 \%$ & $88.5 \%$ & $77.7 \%$ & $33.4 \%$ & $8.6 \%$ & $28.2 \%$ \\
\hline Latvia & $77.4 \%$ & $60.0 \%$ & $52.6 \%$ & $62.0 \%$ & $76.7 \%$ & $71.8 \%$ & $33.4 \%$ & $8.4 \%$ & $19.0 \%$ \\
\hline Lithuania & $49.9 \%$ & $30.9 \%$ & $33.7 \%$ & $58.6 \%$ & $73.3 \%$ & $59.2 \%$ & $17.8 \%$ & $21.0 \%$ & $61.5 \%$ \\
\hline Netherlands & $91.7 \%$ & $88.4 \%$ & $84.6 \%$ & $80.4 \%$ & $77.2 \%$ & $71.0 \%$ & $38.8 \%$ & $8.8 \%$ & $59.1 \%$ \\
\hline Norway & $60.7 \%$ & $40.0 \%$ & $61.3 \%$ & $64.2 \%$ & $78.9 \%$ & $85.0 \%$ & $66.6 \%$ & $12.4 \%$ & $19.1 \%$ \\
\hline Portugal & $81.3 \%$ & $72.5 \%$ & $67.8 \%$ & $45.8 \%$ & $43.6 \%$ & $70.6 \%$ & $71.2 \%$ & $30.9 \%$ & $29.1 \%$ \\
\hline & $83.8 \%$ & $83.2 \%$ & $92.0 \%$ & $95.2 \%$ & $91.2 \%$ & $82.8 \%$ & $51.3 \%$ & $18.4 \%$ & $60.3 \%$ \\
\hline akia & $.0 \%$ & $30.1 \%$ & $37.9 \%$ & $45.9 \%$ & $35.1 \%$ & $10.9 \%$ & $6.2 \%$ & $17.6 \%$ & $25.1 \%$ \\
\hline Slovenia & $85.2 \%$ & $76.7 \%$ & $72.5 \%$ & $64.9 \%$ & $66.3 \%$ & $63.9 \%$ & $22.2 \%$ & $7.5 \%$ & $44.0 \%$ \\
\hline Spain & $90.1 \%$ & $84.9 \%$ & $82.3 \%$ & $72.9 \%$ & $71.6 \%$ & $73.7 \%$ & $50.2 \%$ & $2.8 \%$ & $28.6 \%$ \\
\hline Sweden & $90.0 \%$ & $90.4 \%$ & $83.6 \%$ & $77.1 \%$ & $86.5 \%$ & $76.4 \%$ & $25.2 \%$ & $6.0 \%$ & $35.3 \%$ \\
\hline Switzerland & $87.4 \%$ & $72.5 \%$ & $57.8 \%$ & $69.9 \%$ & $87.6 \%$ & $77.9 \%$ & $25.7 \%$ & $8.9 \%$ & $38.0 \%$ \\
\hline Turkey & $71.4 \%$ & $63.3 \%$ & $77.7 \%$ & $89.7 \%$ & $83.7 \%$ & $42.5 \%$ & $3.2 \%$ & $1.9 \%$ & $35.0 \%$ \\
\hline EU 27 & $86.5 \%$ & $83.0 \%$ & $82.1 \%$ & $83.8 \%$ & $86.8 \%$ & $76.3 \%$ & $30.0 \%$ & $13.8 \%$ & $63.2 \%$ \\
\hline Euro 17 & $86.5 \%$ & $81.5 \%$ & $80.0 \%$ & $83.7 \%$ & $87.9 \%$ & $78.4 \%$ & $33.0 \%$ & $14.0 \%$ & $63.9 \%$ \\
\hline
\end{tabular}


North and South America

\begin{tabular}{|c|c|c|c|c|c|c|c|c|c|}
\hline Country & 30 & 20 & 15 & 12 & 10 & 8.57 & 7.5 & 6.67 & 6 \\
\hline Argentina & $64.0 \%$ & $20.3 \%$ & $25.2 \%$ & $22.5 \%$ & $17.1 \%$ & $3.9 \%$ & $3.1 \%$ & $40.2 \%$ & $88.0 \%$ \\
\hline Bolivia & $14.0 \%$ & $25.1 \%$ & $52.0 \%$ & $28.9 \%$ & $73.7 \%$ & $62.3 \%$ & $32.2 \%$ & $34.4 \%$ & $18.8 \%$ \\
\hline Brazil & $78.9 \%$ & $79.6 \%$ & $89.9 \%$ & $69.9 \%$ & $69.6 \%$ & $54.4 \%$ & $6.2 \%$ & $21.2 \%$ & $18.3 \%$ \\
\hline Chile & $37.6 \%$ & $19.5 \%$ & $56.6 \%$ & $65.1 \%$ & $87.3 \%$ & $86.7 \%$ & $59.7 \%$ & $72.4 \%$ & $83.5 \%$ \\
\hline Canada & $88.6 \%$ & $84.9 \%$ & $78.6 \%$ & $81.0 \%$ & $87.5 \%$ & $66.8 \%$ & $15.4 \%$ & $4.6 \%$ & $29.4 \%$ \\
\hline Colombia & $10.0 \%$ & $19.5 \%$ & $32.7 \%$ & $48.4 \%$ & $76.9 \%$ & $77.7 \%$ & $67.9 \%$ & $64.7 \%$ & $43.9 \%$ \\
\hline Mexico & $81.3 \%$ & $78.1 \%$ & $80.1 \%$ & $88.0 \%$ & $90.1 \%$ & $58.2 \%$ & $8.8 \%$ & $18.0 \%$ & $61.5 \%$ \\
\hline Peru & $44.1 \%$ & $35.0 \%$ & $34.3 \%$ & $27.6 \%$ & $67.3 \%$ & $79.6 \%$ & $31.5 \%$ & $23.8 \%$ & $35.8 \%$ \\
\hline USA & $88.4 \%$ & $89.7 \%$ & $88.2 \%$ & $88.0 \%$ & $81.2 \%$ & $57.9 \%$ & $11.4 \%$ & $7.7 \%$ & $24.1 \%$ \\
\hline \multicolumn{10}{|l|}{ Asia } \\
\hline Country & 30 & 20 & 15 & 12 & 10 & 8.57 & 7.5 & 6.67 & 6 \\
\hline China & $83.1 \%$ & $60.7 \%$ & $31.3 \%$ & $43.9 \%$ & $57.8 \%$ & $63.2 \%$ & $38.9 \%$ & $1.7 \%$ & $61.1 \%$ \\
\hline H. Kong & $53.0 \%$ & $53.5 \%$ & $70.9 \%$ & $70.0 \%$ & $86.1 \%$ & $78.0 \%$ & $36.6 \%$ & $13.3 \%$ & $45.4 \%$ \\
\hline India & $51.7 \%$ & $18.9 \%$ & $62.6 \%$ & $43.6 \%$ & $9.4 \%$ & $22.2 \%$ & $5.4 \%$ & $61.5 \%$ & $84.4 \%$ \\
\hline Indonesia & $53.0 \%$ & $36.2 \%$ & $43.4 \%$ & $2.4 \%$ & $31.2 \%$ & $66.8 \%$ & $60.1 \%$ & $76.8 \%$ & $81.0 \%$ \\
\hline Iran & $1.6 \%$ & $14.4 \%$ & $54.7 \%$ & $58.9 \%$ & $29.0 \%$ & $20.3 \%$ & $15.6 \%$ & $20.7 \%$ & $44.5 \%$ \\
\hline Israel & $64.1 \%$ & $52.7 \%$ & $62.1 \%$ & $76.7 \%$ & $77.1 \%$ & $44.3 \%$ & $4.1 \%$ & $11.7 \%$ & $6.5 \%$ \\
\hline Japan & $50.2 \%$ & $54.6 \%$ & $79.8 \%$ & $85.6 \%$ & $72.7 \%$ & $45.0 \%$ & $16.0 \%$ & $1.9 \%$ & $14.2 \%$ \\
\hline Malaysia & $12.3 \%$ & $41.6 \%$ & $79.9 \%$ & $75.8 \%$ & $83.1 \%$ & $80.0 \%$ & $45.1 \%$ & $29.5 \%$ & $65.1 \%$ \\
\hline Philippines & $54.9 \%$ & $4.9 \%$ & $40.2 \%$ & $31.5 \%$ & $10.5 \%$ & $29.9 \%$ & $24.7 \%$ & $24.8 \%$ & $44.7 \%$ \\
\hline Singapore & $68.7 \%$ & $68.1 \%$ & $81.4 \%$ & $86.6 \%$ & $84.8 \%$ & $71.6 \%$ & $40.7 \%$ & $42.2 \%$ & $52.5 \%$ \\
\hline S. Korea & $36.0 \%$ & $41.2 \%$ & $62.8 \%$ & $49.8 \%$ & $72.6 \%$ & $78.5 \%$ & $42.3 \%$ & $27.4 \%$ & $61.9 \%$ \\
\hline Taiwan & $77.9 \%$ & $83.2 \%$ & $90.1 \%$ & $87.7 \%$ & $80.6 \%$ & $48.1 \%$ & $9.3 \%$ & $2.4 \%$ & $36.9 \%$ \\
\hline Thailand & $9.4 \%$ & $38.2 \%$ & $75.8 \%$ & $62.6 \%$ & $60.2 \%$ & $68.1 \%$ & $40.4 \%$ & $29.9 \%$ & $67.8 \%$ \\
\hline \multicolumn{10}{|c|}{ Australia and Oceania } \\
\hline Country & 30 & 20 & 15 & 12 & 10 & 8.57 & 7.5 & 6.67 & 6 \\
\hline Australia & $16.8 \%$ & $7.5 \%$ & $36.9 \%$ & $63.2 \%$ & $49.1 \%$ & $25.9 \%$ & $3.5 \%$ & $26.8 \%$ & $27.6 \%$ \\
\hline N.Zealand & $66.7 \%$ & $70.2 \%$ & $86.1 \%$ & $77.4 \%$ & $81.2 \%$ & $78.5 \%$ & $53.9 \%$ & $26.8 \%$ & $2.7 \%$ \\
\hline \multicolumn{10}{|l|}{ Africa } \\
\hline Country & 30 & 20 & 15 & 12 & 10 & 8.57 & 7.5 & 6.67 & 6 \\
\hline Moroc & $36.6 \%$ & $17.4 \%$ & $28.2 \%$ & $49.5 \%$ & $76.3 \%$ & $57.2 \%$ & $15.7 \%$ & $33.1 \%$ & $35.5 \%$ \\
\hline & $68.0 \%$ & $60.7 \%$ & $65.5 \%$ & $60.7 \%$ & $63.3 \%$ & $51.1 \%$ & $6.4 \%$ & $17.4 \%$ & $67.4 \%$ \\
\hline
\end{tabular}

Source: authors' own calculations based on World Bank data

\section{Conclusions}

Relations between economic variables can be superficial or accidental, but assuming that the domestic US consumer demand, encouraging the role of the U.S. investment funds for other investors, rating agencies and the U.S. stock exchanges create information-and sentiment-based transmission channels, it is hard to ignore the evidence that a long-term Poland's cycle seems to be highly dependent on the changes in the US economy (Poland is preceded by the U.S. economy by 1-2 quarters, depending on the analyzed frequency). What is more, until recently, Poland preceded almost all EU economies lagging behind very few world economies, including the U.S. one. Therefore, it is difficult to reject the 
hypothesis that whatever happens in the U.S. will find be followed by changes in Polish economy and, consequently, by all other countries all over the world, if one analyzes long-term frequencies that reflect strong economic trends lasting longer than 2 years.

Cutting the long story short, if one assumes that the presented results do not originate in imperfections of chosen econometric methods, one should reject the decoupling hypothesis for at least long business cycles and support the notion of a strong synchronization of the path of GDP changes.

The synchronization became especially visible during the last global financial crisis. Some countries, like China, showed some resistance in the presence of the global shocks (at the same time influencing other countries), but generally the cyclical part of GDP in both advanced and emerging countries deflected down in relation to the GDP long-term trend (Kim et al., 2009).

Hence, there seems to exist evidence of quite a strong synchronization of GDP changes between advanced and emerging economies which raises the question whether the high rates of growth in emerging economies are sustainable without a recovery in advanced economies.

From the investors' points of view, with all previously mentioned limitations of the obtained results and the research method, one can draw the following conclusions (especially, from the Poland's perspective). More and more researchers including the authors of this paper undermine the theory of decoupled growth rates between emerging and developed economies, especially during strong disturbances in the global financial market (but not only during crises, also in the long-term perspective). There are certainly country and regional factors influencing the behavior of the business cycles of the emerging economies (which impacts the value of investments in these countries) but the global factor and the business cycles of the biggest world economies (such as or primarily the USA) cannot be marginalized. Emerging economies, especially in the short-term perspective, can be resistant to economic downturns influencing developed countries, but the obtained results suggest that in the long-term perspective emerging economies are going to follow the same trends. Investors cannot assume that in the long-term 
perspective the general recession in the developed countries is not going to significantly hinder the growth of the emerging countries.

\section{References}

Adamowicz, E.; Dudek, S.; Pachucki, D.; Walczyk, K. (2009). Synchronizacja cyklu koniunkturalnego polskiej gospodarki z krajami strefy euro w kontekście struktury tych gospodarek, in Raport na temat pełnego uczestnictwa Rzeczypospolitej Polskiej w trzecim etapie Unii Gospodarczej i Walutowej, Projekty badawcze cz. I.Warszawa: NBP.

Bloomfield, P. (1976). Fourier analysis of time series. New York: Wiley.

Chatfield C. (1996). The Analysis of Time Series, An Introduction. Boca Raton, London, New York, Washington: Chapman and Hall/CRC Texts in Statistical Science.

Christiano L.; Fitzgerald T. (1999). The Band Pass Filter. Federal Reserve Bank of Cleveland Working Paper 9906.

Decoupling 2.0: The biggest emerging economies will recover faster than America, (2009). The Economist, May 21, 2009.

Dervis, K. (2012). Convergence, Interdependence, and Divergence. Finance and Development, September 2012.

Hartmann D., Objective analysis course notes, Cross Spectrum Analysis, p. 168. [online] [accessed 1 July 2012]. Available from Internet: <http://www.atmos.washington.edu/ dennis/552_Notes_6c.pdf > .

Hamilton, J. D. (1994). Time series analysis. Princeton: Princeton University Press. ISBN10-0691042896.

Kim, S.; Lee, J.-L.; Park, C.-Y. (2009). Emerging Asia: Decoupling or Recoupling. $A D B$ Working Paper Series on Regional Economic Integration, No. 31.

Konopczak, K. (2009). Analiza zbieżności cyklu koniunkturalnego gospodarki polskiej ze strefa euro na tle krajów Europy ŚrodkowoWschodniej oraz państw członkowskich strefy euro, in Raport na temat pełnego uczestnictwa Rzeczypospolitej Polskiej w trzecim etapie Unii Gospodarczej i Walutowej, Projekty badawcze cz. I. Warszawa: NBP.

Korinek, A.; Roitman, A.; Vegh, C. (2010). Decoupling and Recoupling. American Economic Review 100(2), pp. 393-397. 
Kose, M.; Otrok, Ch.; Prasad, E. S. (2008). Global Business Cycles: Convergence or Decoupling? NBER Working Paper No. 14292.

Kose, M.; Prasad, E. S. (2010). Emerging Markets: Resilience and Growth amid Global Turmoil. Washington, D.C.: Brookings Institution Press.

Krugman, P. (2010). We Are Not The World. The New York Times. November 9, 2010. [online] [accessed 1 July 2012]. Available from Internet: <http://krugman.blogs.nytimes.com/2010/11/09/we-are-notthe-world/>

Nilsson, R.; Gyomai G. (2011). Cycle extraction, OECD. [online] [accessed 1 July 2012]. Available from Internet: <http://www.oecd.org>.

Rose, A, (2009). Debunking decoupling. VOX. [online] [accessed 1 July 2012]. Available from the Internet: http://www.voxeu.org/person/ andrew-k-rose>

Skrzypczyński, P. (2010). Metody spektralne w analizie cyklu koniunkturalnego gospodarki polskiej. Materiały i Studia NBP, No. 252.

Skrzypczyński, P. (2008). Wahania aktywności gospodarczej w Polsce i strefie euro. Materiały i Studia NBP, no. 227.

Wälti, S. (2009). The myth of decoupling. [online] [accessed 1 July 2012]. Available from the Internet: <http://mpra.ub.umi-muenchen.de>.

World Economic Outlook. Spillovers and Cycles in the Global Economy 2007. Washington, D.C.: IMF.

Yeyati, E. L.; Williams, T. (2012). Emerging economies in the 2000s: Real decoupling and financial recoupling. The Policy Research Working Paper 5961. Washington, D.C.: The World Bank. 